\title{
Geologic Map of the Castle Rock 7.5' Quadrangle, Arizona and California
}

By P. Kyle House, Barbara E. John, Daniel V. Malmon, Debra Block, L. Sue Beard, Tracey J. Felger, Ryan S. Crow, Jonathan E. Schwing, and Colleen E. Cassidy

Pamphlet to accompany

Scientific Investigations Map 3411

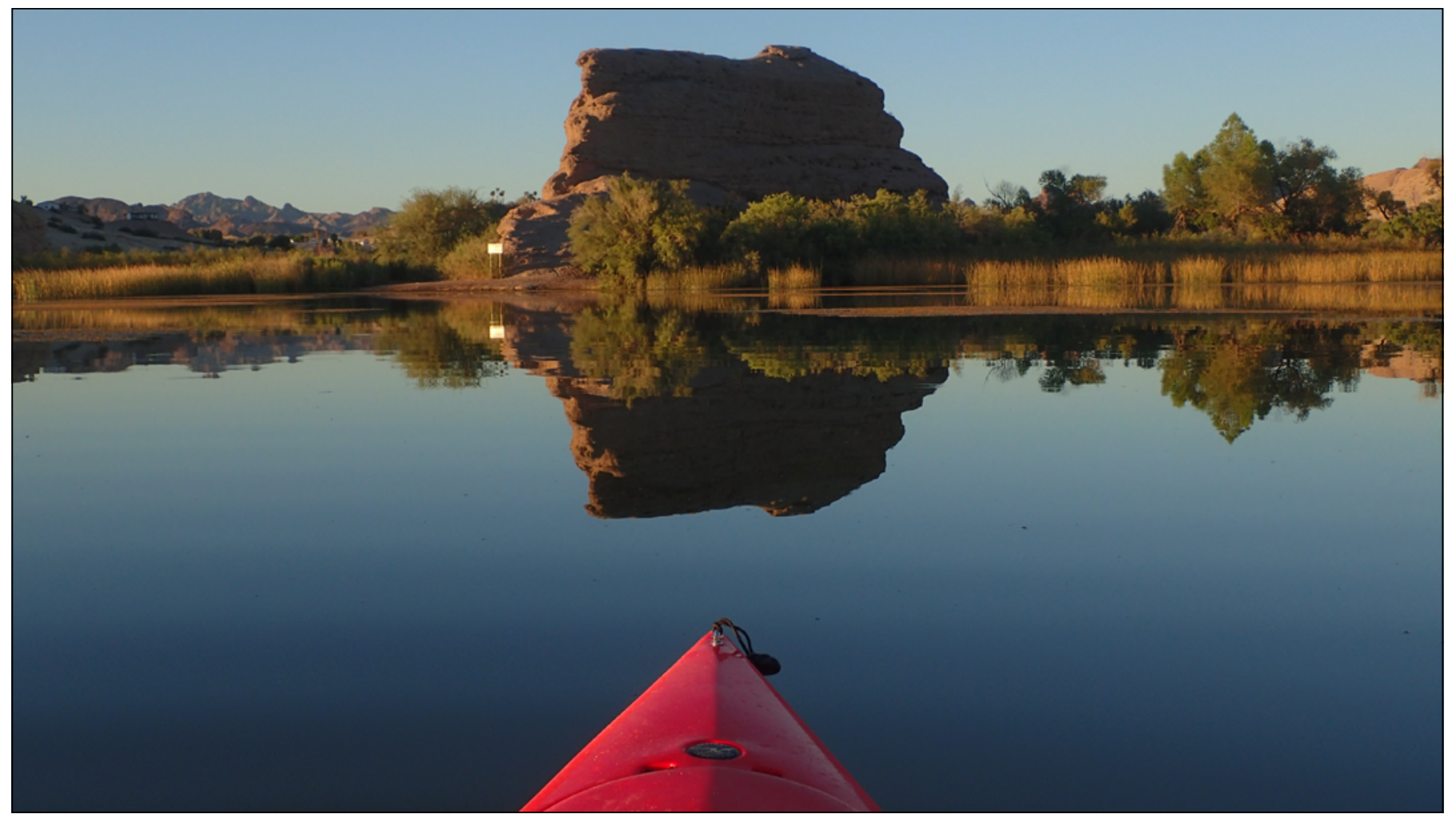

Kayaker's view of Castle Rock (unit Tac) looking north-northeast from Castle Rock Bay, Arizona. The northern Mohave Mountains are visible in left background, and sediments of the Chemehuevi Formation (unit Qch) are seen along right edge of photo. Photograph taken August 27, 2014, by Kyle House, USGS. 


\section{U.S. Department of the Interior \\ RYAN K. ZINKE, Secretary \\ U.S. Geological Survey \\ James F. Reilly II, Director}

\section{U.S. Geological Survey, Reston, Virginia: 2018}

For more information on the USGS - the Federal source for science about the Earth, its natural and living resources, natural hazards, and the environment-visit

https://www.usgs.gov/ or call 1-888-ASK-USGS (1-888-275-8747).

For an overview of USGS information products, including maps, imagery, and publications, visit https://store.usgs.gov.

To order USGS information products, visit https://store.usgs.gov/.

Any use of trade, firm, or product names is for descriptive purposes only and does not imply endorsement by the U.S. Government.

Although this information product, for the most part, is in the public domain, it also may contain copyrighted materials as noted in the text. Permission to reproduce copyrighted items must be secured from the copyright owner.

Suggested citation:

House, P.K., John, B.E., Malmon, D.V., Block, Debra, Beard, L.S., Felger, T.J., Crow, R.S., Schwing, J.E., and Cassidy, C.E., 2018 , Geologic map of the Castle Rock 7.5' quadrangle: U.S. Geological Survey Scientific Investigations Map 3411, 15 p., 1 sheet, scale 1:24,000, https://doi.org/10.3133/sim3411.

ISSN 2329-132X (online) 


\section{Contents}

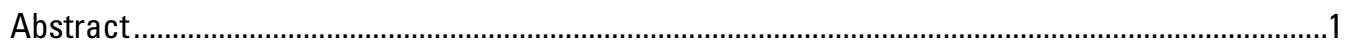

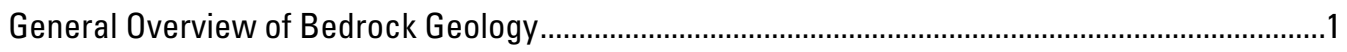

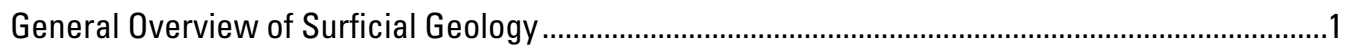

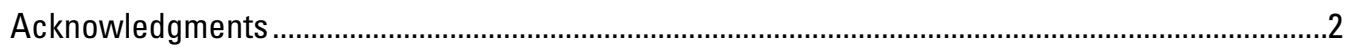

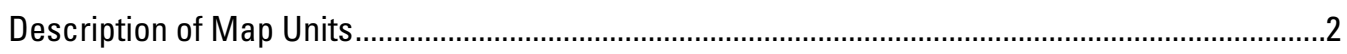

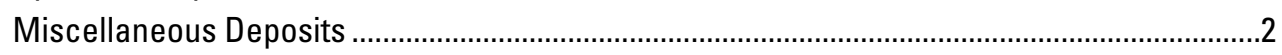

Piedmont Alluvium of the Mohave and Chemehuevi Mountains.................................................2

Alluvium of the Colorado River and Related Deposits ...........................................................

Basin-fill Sediments (Post-extensional).................................................................................

Alluvial and Megabreccia Deposits (Syn-extensional) ........................................................10

Cenozoic Volcanic Rocks and Sediments........................................................................

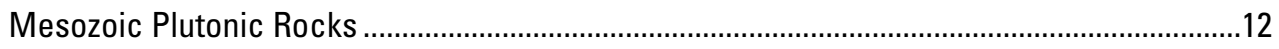

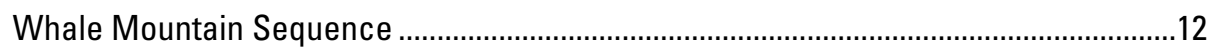

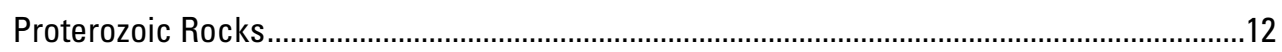

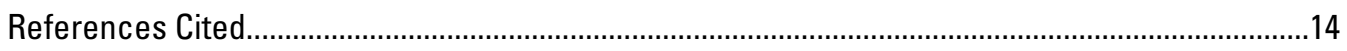

\section{Table}

1. Data for microfossil samples collected by P.K. House and analyzed by Kristin McDougall....13 



\section{Abstract}

The Castle Rock quadrangle is in the northeast corner of Chemehuevi Valley, California and Arizona. It includes the Colorado River's entrance to the valley at the mouth of Topock Gorge and the northern outskirts of Lake Havasu City, Arizona, and the Chemehuevi Indian Tribe community of Havasu Lake, California. The map includes large parts of the Chemehuevi Indian Reservation and the Havasu National Wildlife Refuge. Upon its exit through the mouth of Topock Gorge, the Colorado River enters Chemehuevi Valley where its floodplain (now submerged under Lake Havasu) is flanked by alluvial piedmonts of the Chemehuevi and Mohave Mountains to the west and east, respectively. This abrupt transition offers a useful perspective into the structural evolution of the Colorado River extensional corridor and of the Colorado River itself. It contains key structural and stratigraphic elements recording a complex history of Cretaceous plutonism and deformation, significant tectonic extension, volcanism, and sedimentation in the Miocene, and, ultimately, the evolution of the Colorado River from the latest Miocene to the present. Lake Havasu submerged the axis of Chemehuevi Valley following the completion of Parker Dam in 1938, and the Colorado River now feeds a verdant delta marsh that composes part of the map. Important bedrock units include the Cretaceous Chemehuevi Mountains Plutonic Suite, the 18.78 Ma Peach Spring Tuff, and thick overlying sequences of interlayered Miocene megabreccia and fanglomerate. The exposure of these units is closely linked to extension along the Chemehuevi-Whipple Mountains detachment fault system. The complex bedrock geologic framework serves as the structural and topographic foundation for the key strata chronicling the evolution of the lower Colorado River. Important stratigraphic units that bear on its evolution to the present day include the Bouse Formation, the Bullhead Alluvium, and the Chemehuevi Formation. The map area also contains the river's modern delta at the head of Lake Havasu.

\section{General Overview of Bedrock Geology}

The Castle Rock quadrangle includes many spectacularly well exposed rocks that record the effects of tectonic extension and unroofing and tectonic denudation of a part of a major metamorphic core complex in the lower Colorado River extensional corridor. Tectonic extension was accompanied by, and interspersed with, regional volcanic activity and accelerated sedimentation related to increasing relief, crustal thinning, and seismicity (John, 1987b, 1988; Miller and John, 1999; Howard and others, 2013).

Rapid tectonic extension in the region began approximately 18-19 Ma (Howard and others, 2013) around the time of the eruption and deposition of the Peach Spring Tuff, an important marker bed in the map area and the region. Progressive crustal extension along a system of low-angle detachment faults resulted in the exhumation of deep-seated Proterozoic and Mesozoic crystalline rocks (lower plate rocks) from beneath a cover of various sedimentary and volcanic rocks (upper plate rocks). Low-angle separation of the upper plate and lower plate assemblages was accompanied by high-angle normal faulting and related rotation of upper plate rocks. Erosion of upper- and lower-plate rocks was rapid during tectonic extension and related faulting and seismic activity. Syn-extensional sedimentary deposits include rocks that reflect the formation of relief, erosion of uplifting rocks, and deposition of sedimentary detritus in evolving fault-bounded basins. The syn-extensional sedimentary rocks include lacustrine and fluvial siltstones and sandstones; alluvial fan conglomerates (fanglomerates); and rock avalanche megabrecccias. The fanglomerates and megabreccias are interstratified and have lithologic compositions that record the progressive denudation of the Chemehuevi Mountains to deeper structural levels. As such, their compositions are inverted relative to the rocks in the mountain core. Increasingly younger sediments are composed of progressively structurally deeper rocks in the mountains (John, 1988; Miller and John, 1999; Howard and others, 2013). Significant tectonic extension had ceased by the late Miocene.

\section{General Overview of Surficial Geology}

Surficial geologic deposits in the Castle Rock quadrangle encompass all of the mostly undeformed, post-extensional sedimentary deposits and carbonate deposits derived from the Chemehuevi and Mohave Mountains and the nascent to modern Colorado River. The map area contains a suite of surficial strata that records the transition of northern Chemehuevi Valley from an actively extending intermontane basin into a tectonically quiescent valley, flanked by rugged mountains and the alluvial fans draining them. The largely post-tectonic influences of the early Pliocene arrival of the Colorado River, and its subsequent evolution, have dominated the evolution of the Chemehuevi Valley landscape.

The pre-Colorado River strata in the valley show decreasing tectonic influence over time, so progressively younger strata are progressively less deformed. The oldest unit in the map area that begins the post-tectonic regime is Tfo (older fanglomerate). Unit Tfo includes alluvial fan, wash, and bouldery paleochannel-fill deposits. The unit has sedimentary fabrics indicating north-south transport of fluvial gravel and sand, but none of them contains particles indicative of Colorado River origin. Wave-worked sediment, marl, and muds of the Bouse Formation overlie the Tfo package of units. The Bouse Formation (unit Tbo) is the primordial deposit of the nascent lower Colorado River, and it is likely that it was deposited as lacustrine and deltaic deposits into standing water, probably a lake but possibly an estuary.

The end of Bouse deposition in the valley was a likely response to a major drop in local base level. The newly integrated lower Colorado River was directly linked with the proto-Gulf of California and deposited the Bullhead Alluvium (unit Tcb). Large flood events that deposited boulder and large-cobble conglomerates, interspersed with finer grained fluvial deposits of cross-bedded sand and pebble gravels, may have accompanied the initiation of river integration. The early Pliocene aggradation of the Bullhead Alluvium culminated in an alluvial fill as thick as $200 \mathrm{~m}$ between about 4.5 and 3.5 Ma. High-standing remnants of this deposit were not identified in the Castle Rock quadrangles, but detrital clasts of Colorado River gravel have been identified in unit QTa at relatively high positions in the 
landscape. Subsequently, a protracted episode of net incision into the fill extended into the late Pleistocene. In this long interval, only one early Pleistocene Colorado River stratigraphic unit, the alluvium of Palo Verde Mesa (unit Qcp), was deposited and tentatively identified in this map area. Otherwise, the long-term trend of deep, net incision into the Bullhead alluvial fill was not significantly reversed until the deposition of the Chemehuevi Formation (unit Qch) in the late Pleistocene (70 ka). PostChemehuevi erosion in the late Pleistocene left behind a series of sandy gravel terraces, both cut and fill, which line piedmont slopes leading to the shores of Lake Havasu. Late Pleistocene erosion possibly continued into the early Holocene and was followed by an aggradational episode that culminated in the modern floodplain, which has been submerged by the lake for 80 years. Deposits of the Colorado River delta are its youngest in the map area.

\section{Acknowledgments}

Mapping was supported by the U.S. Geological Survey (USGS) National Cooperative Geologic Mapping Program, the USGS Mendenhall Fellowship Program (to D.V. Malmon) and the National Science Foundation (grants EAR-9405175 and 1145183 to B.E. John). Elizabeth Mennow provided support with samples and field data organization. Frederick Rivera of the Chemehuevi Indian Tribe Dept. of Conservation generously provided boat support on Lake Havasu. Keith Howard and Phil Pearthree contributed to field observations in the map area by providing field notes and participation in some reconnaissance work with House. Jonathan Schwing provided field assistance. Howard and Pearthree also provided detailed reviews of a preliminary version of the map. Stephanie Dudash reviewed the GIS data. Jan Zigler and Claire Landowski provided editorial and cartographic assistance.

\section{DESCRIPTION OF MAP UNITS}

[Note: Not shown on this map are swarms of Tertiary and Cretaceous(?) dikes that intrude rocks below the Chemehuevi detachment fault (LaForge and others, 2017). The dikes are dark greenish gray to black, gray, and tan. The dikes are highly variable in composition and texture; range in composition from coarse-grained hornblende diorite and olivine gabbro to biotite-bearing dacite porphyry; and are centered in the Chemehuevi Mountains Plutonic Suite. Dark-weathering diabase dikes form a major intrusive phase. Diabase dikes are typically fine to medium grained and subophitic and contain plagioclase and pyroxene. In the western part of the Chemehuevi Mountains, massive, subvertical northeast-trending lamprophyre dikes are common. They are characterized by two generations of amphibole, a very heterogeneous texture, and extreme local alteration. Intermediate to silicic andesite to dacite dikes are gray to tan weathering, with variable phenocryst mineralogy including plagioclase, hornblende, biotite, and potassium feldspar]

\section{MISCELLANEOUS DEPOSITS}

d Disturbed ground (recent) - Areas extensively altered by anthropogenic activities and development, including parts of Lake Havasu City, Arizona, and Havasu Lake, California

Qe Eolian sand deposits (Holocene to upper(?) Pleistocene) - Fine- to medium-grained eolian sand deposits, mostly active. Very well sorted and unconsolidated. Eolian sand is closely associated with the sand-dominated facies of the Chemehuevi Formation (Qchs) and typically forms drapes and climbing ramps on remnants of that deposit. Portions of the deposits may have also been derived from active washes and the pre-dam floodplain of the Colorado River. Relatively large eolian deposits are limited to the Arizona side of the map, the predominantly downwind side of the valley, and where the most extensive Qchs deposits occur. Includes local and patchy swaths of coppice dunes surrounding swaths of creosote bushes and irregular and sparsely vegetated sheets on slopes and in small valleys. Dune orientations and coppice-dune morphology indicates predominantly southwest to northeast transport. Maximum thickness generally less than $3 \mathrm{~m}$

\section{PIEDMONT ALLUVIUM OF THE MOHAVE AND CHEMEHUEVI MOUNTAINS}

Piedmont alluvium includes sediments deposited by ephemeral washes and alluvial fans emanating from the Chemehuevi and Mohave Mountains and from erosion of relict fan and terrace landforms on the piedmont. This group of units and associated landforms postdate significant tectonic activity in the valley and spans the late Miocene to the present, with the bulk of the suite dating to the Holocene and late Pleistocene. Deposits are subdivided chronologically based on stratigraphic and morphologic relations with each other and with Colorado River deposits. Morphology-based mapping criteria include type of active surface drainage pattern (for example, distributary-constructional or dendritic-erosional); depth of dissection by surface drainage; extent and degree of smoothing of primary depositional topography; presence and nature of surface pavement development; degree of clast varnish development; and soil development, particularly soil carbonate horizon development. Aspects of these criteria are time dependent and follow relatively predictable trajectories on piedmont landforms that are not actively forming through primary depositional processes. Lithologic composition and sedimentary texture of the deposits 
and their substrates affect their morphological development; for example, piedmont deposits in the map area that are underlain by sediment derived from volcanic rocks typically support more stable surfaces over time than do areas underlain by sediment derived from coarsely crystalline rocks. In general, piedmont deposits underlain by relatively thick exposures of moderately soft- and fine-grained sediments of the Chemehuevi and Bouse Formations are less stable over time than those overlying more indurated strata.

Qy Young piedmont alluvium, undivided (recent to upper Pleistocene) — Sand, gravel, silt, and rare boulder deposits of young washes and alluvial fans on the piedmonts of the Chemehuevi and Mohave Mountains. This undivided unit includes deposits of the youngest active alluvial systems, relatively young abandoned or infrequently active alluvial surfaces, and some areas of young, but abandoned alluvial surfaces. These surfaces and deposits are characterized by active or relict distributary drainage patterns

Active piedmont alluvium (upper to middle Holocene) - Sand, gravel, silt, and rare boulder deposits of active washes and alluvial fans on the Chemehuevi and Mohave Mountains piedmonts. Sediments are poorly to moderately sorted and bedded, subangular to subrounded, and locally derived. Surfaces have pristine bar-and-channel to weakly subdued bar-and-swale topography. Bar-and-channel topography can have up to $1.5 \mathrm{~m}$ of relief. Surfaces are moderately vegetated overall with both dispersed and aligned concentrations of desert riparian trees and shrubs. Desert varnish is mostly lacking and deposit surfaces are generally light toned in the field and in aerial imagery. Soil development is also mostly lacking in these deposits, but cryptogamic crust may be present on older bars and swales that impart a slightly dark tone. Surfaces of active alluvial fans have distinctive distributary patterns in aerial imagery. Surfaces of active washes are typically braided. Broadly correlative to unit Q4 of Bull (1991) and Dickey and others (1980). Thickness estimated to be 1 to $3 \mathrm{~m}$

Inactive piedmont alluvium (middle Holocene to upper Pleistocene) - Sand, gravel, silt, and rare boulder deposits of relatively young, inactive washes and alluvial fans on piedmonts of the Chemehuevi and Mohave Mountains. Sediments are poorly to moderately sorted and bedded, subangular to subrounded, and locally derived. Relict depositional fabric is discernible on most surfaces of this unit. Minimal to no evidence of recent fluvial activity is present. Surfaces have obvious, but somewhat muted, bar-and-channel to bar-and-swale topography with up to $1 \mathrm{~m}$ relief. Surface clasts commonly are weakly to moderately varnished with a light- to moderate-brown tint. Deposit surfaces are sparsely vegetated relative to Qy2. Soil development is weak. Stage 1 carbonate horizons (for example, Machette, 1985) are common, and incipient Av horizons are present in loosely paved swales. Unit is dispersed over large extent of the Chemehuevi Mountains piedmont in a pattern suggesting an original distribution similar to Qy2. Remnants are located adjacent to active washes, are dispersed within broad active flow swaths, and span the extent of abandoned flow swaths. Age uncertain but surface character suggests latest Pleistocene through middle Holocene. May correlate to units Q2c and Q3a of Bull (1991), whose age is estimated to be between 11 and $2 \mathrm{ka}$, primarily based on soil and surface characteristics. Unit may be equivalent to parts of the young alluvium (Q3) of Dickey and others (1980) and (or) unit 3 (Qs3) of Howard and others (1999). Typically, 1-4 m thick above active washes; greater thicknesses are probably concealed

Pleistocene) - Unconsolidated to weakly consolidated sand, gravel, silt, and rare boulder deposits of terraces and alluvial fans on the piedmonts of the Chemehuevi and Mohave Mountains. Sediments are poorly to moderately sorted and bedded, subangular to subrounded, and locally derived. Intermediate-age surfaces include relict alluvial fan and fan terraces that are isolated from active, constructional fluvial processes but do host local, typically dendritic drainage networks. Three divisions of this unit are present in this map: Qi2, Qi3, and Qi4. Only Qi2 definitively predates the Chemehuevi Formation deposits of inactive washes and alluvial fans on the Chemehuevi and Mohave Mountains piedmonts. Sediments are poorly to moderately sorted and bedded, subangular to subrounded, and locally derived. Weak soil development with moderate Bw horizons and Stage I to II soil carbonate horizon development. This unit postdates unit Qcr3 and cuts and is inset against Qi3 and older units in most locations. Moderate varnish on clasts. Moderate gravel lags to weak pavements particularly in swales. Depositional topography weakly to moderately muted; coarse bars and weakly to moderately paved swales are 
evident in field. Equivalent to Qi3c on Arizona Geological Survey maps. Unit Qi4 is not included as subunit of Qi3 though its morphologic characteristics are similar to Qi3a and Qi3b and the three units can be difficult to distinguish in upper piedmont areas where their topographic separation can be minor. Qi4 is generally similar to Q2b and Q3 of Dickey and others (1980), unit Qs3 of Wilshire and Reneau (1992) and Howard and others (1999), and unit Qi3c of Gootee and others (2016)

Unit 4b (lower Holocene(?) to upper Pleistocene) - Weakly consolidated to unconsolidated, poorly sorted and bedded, subangular to subrounded locally derived sand, pebbles, cobbles, and rare boulders. Deposit surfaces have subdued bar-and-swale topography and distinct pinnate texture in aerial imagery. Surface clasts have moderately dark varnish and swales between bar crests have moderate to strongly developed pavements. Deposits have stage I to II pedogenic carbonate morphology. Correlative to unit Q3b of Dickey and others (1980), unit Q3b of Wilshire and Reneau (1992) and Howard and others (1999), and units Q2b and Q2c of Bull (1991)

Unit 4a (upper Pleistocene) - Weakly consolidated to unconsolidated, poorly sorted and bedded, subangular to subrounded locally derived sand, pebbles, cobbles, and rare boulders. Surfaces show minimal primary depositional topography with well-developed, strongly varnished pavements. Unit Qi4a deposit surfaces resemble those of Qi3a and Qi3b but cut them and deposits of unit Qch in middle to lower piedmont area. Deposits have stage II to III pedogenic carbonate morphology. Correlative to unit Q1b of Dickey and others (1980), unit Qi3a of Wilshire and Reneau (1992), and units Q2b and (or) Q2c of Bull (1991)

Unit 3 (upper Pleistocene) - Poorly sorted, poorly bedded, subangular to subrounded locally derived sand, pebbles, cobbles, and rare boulders. Deposits are as thick as $20 \mathrm{~m}$, but typically less. Unit may contain rare pebbles from older Colorado River deposits. Division of unit Qi3 into two subunits is made on the basis of observable relations to the Chemehuevi Formation but is an inference in some places. Subunit Qi3a appears to be roughly coeval with peak aggradation of Chemehuevi sediments. Near the north edge of the Arizona portion of the quadrangle, Qi3a surfaces may be coeval with the highest strata of Qch on the piedmont (approximately $205-210 \mathrm{~m}$ in that area). In contrast, Qi3b alluvium truncates Qch deposits such that pristine surface remnants atop unit Qch extend well below the 205-210 m level. Undivided variant (Qi3) of this unit shown in areas where difficult or impractical to differentiate subunits. Morphological variability is minor and soil development is similar between the subunits. On the Mohave Mountains piedmont, Qi3 deposits are smooth with well-developed and darkly varnished pavements. On the central to southern Chemehuevi Mountains piedmont, unit Qi3 surfaces are slightly to moderately degraded. Tight desert pavements are common on well-preserved surfaces. Qi3 deposits host moderately developed soils with stage II to III pedogenic carbonate morphology. Unit may be equivalent to parts of the intermediate alluvium (Q2a and Q2b) of Dickey and others (1980) and (or) unit 2 (Qs2) of Wilshire and Reneau (1992) and Howard and others (1999)

Unit 3b (upper Pleistocene) - Weakly consolidated to unconsolidated, poorly sorted and bedded, subangular to subrounded locally derived sand, pebbles, cobbles, and rare boulders. Surfaces have well-developed, strongly varnished pavements, are mostly to completely lacking original depositional bar-and-swale topography, and exhibit stage II to III pedogenic carbonate morphology. Locally includes a series of similar, inset fan lobes in some areas, for example, south of Trampas Wash where a slightly higher and detached lobe is shown as Qi3. This unit is distinctly inset to unit Qi3a in middle and lower piedmont areas. Pristine surfaces of this unit extend well below the top of the Chemehuevi Formation and may be graded to unit Qcr3, though the youngest variants may postdate it somewhat. Thickness varies considerably from about 1 to at least $8 \mathrm{~m}$. This unit is equivalent to parts of the intermediate alluvium (Q2a and Q2b) of Dickey and others (1980); unit Qs2b of Wilshire and Reneau (1992) and Howard and others (1999)

Unit 3a (upper Pleistocene) - Weakly consolidated to unconsolidated, poorly sorted and bedded, subangular to subrounded locally derived sand, pebbles, cobbles, and rare boulders. Surfaces have well-developed, strongly varnished pavements lacking original depositional bar-and-swale topography and exhibiting stage II to III pedogenic carbonate morphology. Unit is interbedded with the Chemehuevi Formation (unit Qch) at various levels and may also postdate that unit's climactic aggradation since it extends slightly below 
the elevation of the highest Qch remnants in the map area. This unit is equivalent to parts of the intermediate alluvium (Q2a and Q2b) of Dickey and others (1980), and unit 2 (Qs2a) of Wilshire and Reneau (1992) and Howard and others (1999). Thickness as much as $20 \mathrm{~m}$. Younger parts of unit may be graded to Colorado River unit

Unit 2 (upper middle to middle(?) Pleistocene) - Relatively high standing fan and fan terrace remnants composed of weakly consolidated to unconsolidated, poorly sorted, poorly bedded, subangular to subrounded sand, gravel, silt, and rare boulders of local origin. Surfaces are smooth overall with rough pavements and darkly varnished clasts. Pavements have moderately to strongly weathered protruding cobble clasts and related fragments, overturned pebble and cobbles, and some carbonate detritus. Deposits have soils with up to stage III pedogenic carbonate. Correlative to unit Q1b of Dickey and others (1980) and tentatively to older parts of unit Qs2a of Wilshire and Reneau (1992) and Howard and others (1999)

QTa Older piedmont alluvium (middle Pleistocene to upper Pliocene(?))-Poorly sorted, poorly bedded silt, sand, gravel, and rare to locally common boulders of local origin. Clasts are angular to subrounded. Contains rare clasts of reworked Bouse limestone and at least one exposure contains rare, rounded quartzite pebbles probably reworked from Tcb. Weakly indurated in some areas, poorly indurated in most. Preserved mainly as a relatively thin, sometimes ridge-like mantle (up to $5 \mathrm{~m}$ ) atop remnants of units Tfo and Tgf near the Chemehuevi Mountains front. Unit QTa also cuts across small remnants composed of several facies of the Bouse Formation that onlap underlying Tfo sediments. Basal contact with them is erosional and has basal cobble conglomerate at some localities. Heavily eroded fan surfaces lack pavement or clear pedogenic carbonate morphology, but varnished clasts and patches of retrograde pavement are present on some sloping surfaces. Deeply weathered clasts (mainly granitic) are relatively common in loose deposits atop ridge crests. May be equivalent to parts of unit C of Metzger and Loeltz (1973); unit QT1 of Dickey and others (1980); unit QTa of Miller and John (1999); and unit QTs1 of Wilshire and Reneau (1992) and Howard and others (1999). Thickness at least $10 \mathrm{~m}$

\section{ALLUVIUM OF THE COLORADO RIVER AND RELATED DEPOSITS}

Alluvium of Blythe, Lake Havasu deltaic facies (1938 to present) - Fine sand, silt, and clay deposited by the modern Colorado River at the head of Lake Havasu. Supports a delta marsh containing low-lying fluvial islands with transient boundaries, isolated backwaters, and extensive grassy marshes. Thickness of unit probably as much as $12 \mathrm{~m}$ based on outcrop locations and pre-dam valley-bottom elevations. Unit also includes fine-grained deposits at tributary mouths and small embayments inundated by the lake; these areas may not contain significant amounts of Colorado River sediment

Qcr Riverside terrace sediments, undivided (upper Pleistocene)-Unconsolidated Colorado River sand and gravel deposits that constitute all or parts of a discontinuous suite of fluvial terraces. Composed of minor fill terraces (up to $6 \mathrm{~m}$ ), thin gravelly and sandy strath veneers, and vanishingly thin deposits or continuous lags of rounded gravel. Terrace sediments have Stage II to III carbonate soil horizons and degraded rhizolith-bearing horizons are present on some older terraces. Large terrace remnants have flat surfaces that slope gently downvalley. Surfaces support moderate to very well developed pavements of moderately to very darkly varnished, well-rounded pebbles and cobbles. Some Qcr deposits may include older, exhumed river-lain strata and thin layers of locally reworked gravels. Surfaces of Riverside terraces (Qcr3, Qcr2, Qcr1) postdate the climactic aggradation of the Chemehuevi Formation, and pre-reservoir topographic maps indicate that additional terraces are present below the surface of Lake Havasu in the map area. The unit has three numbered subunits in order of deposition and decreasing elevation above the lake. Equivalent to young deposits grouped in unit QTr in Dickey and others (1980); unit Qrd of Howard and others (1999); and Qcts of Gootee and others (2016), House and others (2008), House and Faulds (2009), and Spencer and others (2015).

Qcr3 Terrace 3-Unconsolidated to moderately consolidated deposits of sandy, fine- to mediumgrained gravel and sand of the Colorado River. Terrace surfaces have tight, ornate pavements of moderately to very darkly varnished Colorado River gravel clasts. Iridescent varnish is common on these clasts. Calcified wood fragments and rhizoliths are present, though rare. Unit ranges in elevation from 151 to $157 \mathrm{~m}$ along its extent in the map area. 
The large flat surfaces on the California shore of the lake in the southeast corner of the map are the most extensive examples. There, unit Qcr3 ranges from vanishingly thin to as thick as 8-10 $\mathrm{m}$ of Colorado River sand and gravel overlying boulder conglomerate (unit QTcb), Bullhead Alluvium (Tcb), Bouse Formation (Tbo), and late Miocene fanglomerate (Tfo). The thickness of the unit appears to increase toward the south end of the terrace where it may approach $10 \mathrm{~m}$

Terrace 2-Thin, moderately indurated deposits of sandy pebble-cobble gravel that overlie thick sequences of Qchs or Qch. Locally associated indurated horizons are rich with calcified wood and rhizoliths. Forms flat discontinuous surfaces atop unit Qchs at the 183-189 m level in the Arizona part of the map. A prominent erosional scarp in unit Tfo occurs at this level on opposite side of the river, but the gravels inset to that scarp appear older and exhumed (see unit Qchg)

Qcr1 Terrace 1-Thin, moderately indurated deposits of sandy pebble-cobble gravel that overlie thick sequences of Qchs or Qch. Locally associated indurated horizons are rich with calcified wood and rhizoliths. Forms flat discontinuous surfaces atop unit Qchs at the 192-198 m level in the Arizona part of the map. These deposits lie at elevations at least $10 \mathrm{~m}$ below the highest extant Qch and Qchm deposits in the map area. They occur as semi-consolidated beds of sandy, rounded Colorado River pebble to small cobble gravels. Wind-worn clasts, ventifacts, are relatively common on the surface, as are calcified wood fragments and rhizoliths. These surfaces may be exhumed by deflation, but their continuity suggests a terrace landform. Unit generally coincides with the downslope terminus of Qi3a piedmont deposits. Extent is limited to isolated patches atop thick Qchs deposit remnants. Surfaces commonly deflated to carbonate-enriched soil horizons or strata rich with rhizoliths and calcified wood. These terrace remnants are possibly coeval with piedmont unit Qi3a

Qch Chemehuevi Formation, undivided (upper Pleistocene) - Thick and complex sequence of mud, sand, and gravel deposited by the Colorado River in the late Pleistocene. Includes coeval interbedded tributary gravel deposits on outer margins of its outcrop extent and in some deep exposures near the lake. Also includes thin beds and lenses of far-traveled fluvial gravel. Thick and extensive deposits of the Chemehuevi Formation are distributed along a 4- to 5-km-wide, north-south-oriented band on the Mohave Mountain piedmont in Arizona and as a less conspicuous band that crops out in association with a series of scarps on the Chemehuevi Mountains piedmont in California. The stratigraphic base of the unit is not exposed in the map area, but well logs near Castle Rock Bay suggest that Qch may extend up to $20 \mathrm{~m}$ below the level of Lake Havasu and as much as $15 \mathrm{~m}$ below the historical floodplain as shown on historical topographic maps. Maximum thickness in the map area is approximately $105 \mathrm{~m}$. Exposed basal contacts vary considerably in elevation, extending below the lake surface in places and spanning up to $10 \mathrm{~m}$ of vertical relief on paleotopography at several sites. Exposures typically include a distinctive stack of two primary facies: a lower, orangish-pink bluff-forming mud-dominated facies (Qchm) capped with a lighter-toned, slope-forming sand-dominated facies (Qchs). There is substantial (up to $10 \mathrm{~m}$ ) relief along the basal contact of the sequence in the map area. Tephra layers in Chemehuevi Formation sediments upstream of this map area correlate reasonably well with tephra in Owens Lake, California, and Walker Lake, Nevada, whose ages are constrained to 70-74 ka (Malmon and others, 2012). The Chemehuevi Formation includes predominant lithofacies separated by a widespread (regional) unconformity. At several sites in this map area, the contact between the mud-dominated and sand-dominated facies is associated with indurated and oxidized beds of cross-bedded Colorado River sand and gravel. The level of this distinct unconformity within unit Qch also corresponds to erosional surfaces cut on older, indurated deposits (for example, unit Tac near Castle Rock Bay and unit Tfo on the Chemehuevi Mountains piedmont near the central part of the map mud beds, having high proportion of rounded quartz-sand grains deposited by the ancestral Colorado River. This facies is typically weakly consolidated to unconsolidated with poorly exposed stratification, but some exposures show meter-scale tabular cross-bedding; discontinuous beds of imbricated, rounded pebble and cobble gravel; interbedded lenses of locally derived, angular gravel; reddish and pebbly carbonate-rich layers; and discontinuous layers of horizontally bedded and laminated silt and clay $<0.5 \mathrm{~m}$ thick. Found in steep, loose 
slopes lying close to angle of repose of well-sorted, dry sand (about $32^{\circ}$ ). Voluminous unit Qchs remnants are only present on the Arizona side of the quadrangle where they probably track at least one deep paleochannel course on the east side of the steep bluffs southeast along the river from Blankenship Bend. Gravel ventifacts are common on unit Qchs slopes and, particularly, on upper surfaces where aeolian activity is focused. This facies was likely deposited within active channels of a complexly aggrading and degrading Colorado River. Thickness at least $20 \mathrm{~m}$

Mud-dominated facies - Well-bedded sand, silt, and clay deposited by ancestral Colorado River. Commonly consists of discrete beds $5-50 \mathrm{~cm}$ thick of alternating layers of mud and fine to very fine sand. Some interbeds of fine sand exhibit various styles of crossbedding. Large exposures along the Arizona shore of Lake Havasu form distinct lightbrown to pinkish-brown badlands and bluffs. Mud facies exposed beneath thick deposits of sand facies (Qchs) at the apex of Blankenship Bend and near the southeastern corner of quadrangle. Deposited within floodplains bordering an aggrading Colorado River. The highest remnants of Qchm are on the Arizona side of the river on the flanks of steeply dipping flatirons of the Peach Spring Tuff (Tps) near the mouth of Topock Gorge. These remnants are as much as $10 \mathrm{~m}$ higher than the highest Qchs deposits. Locally as thick as $15 \mathrm{~m}$. Some exposures of unit resemble mud deposits of the Bouse Formation. A small fault in muds mapped as Qchm is present in bluff exposures along Lake Havasu along the Arizona shoreline in the southeastern part of the map area

Gravel facies - Cross-bedded sand and pebble to cobble gravel of the Colorado River, moderately to well sorted, commonly oxidized, and loose to moderately indurated. On the Arizona side of the river, unit is exposed in bluffs along the Arizona shore of Blankenship Bend in the north-central part of the map. There, it separates Qchm from Qchs along an erosional unconformity. Exhumed remnants of this oxidized gravelly stratum are also present along Qchm ridges extending from the bluffs. Unit also appears as isolated lenses higher in the Qchs section, but exposures are poor. Similar exhumed gravels are present atop the Castle Rock bluffs along the river's edge extending south from Blankenship Bend. In those areas, the gravel is concordant with fluvial erosion surfaces atop unit Tac. Good exposures of this relation are on the north and south sides of Castle Rock Bay. On the California side of the map, a thin $(<1 \mathrm{~m})$ veneer of darkly varnished and moderately to strongly oxidized gravel sits on a flat surface beveled into unit Tfo. Beveled surfaces are bounded by a prominent fluvial scarp at approximately $189 \mathrm{~m}$ elevation, which is coincident with unit Qcr2. Farther south on the Chemehuevi piedmont, several lowerlying fluvial scarps are associated with thin veneers of fluvial gravel interlayered with linear bands of finer-grained Qch outcrops. It is possible that these gravels are exhumed strata or reworked lags from gravelly intervals of Qchs. However, it is possible (or likely) that the gravels include parts of a Qcr-type unit. It remains indeterminate at this time. Thickness less than $5 \mathrm{~m}$

Qco Older sand and mud deposits (upper Pleistocene) - Weakly to moderately indurated sequence of thin interbedded layers of mud and silt to silty fine sand. Some intervals of rhythmically laminated mud and silt are locally present. In the Blankenship Bend area, this unit underlies a thick bed of piedmont alluvium that underlies Qch in Blankenship Valley. Lithological similarities to unit Qchm (and Tboss) makes identification and division uncertain, and the unit may be more extensive than indicated on the map. Unit may correlate to Needles beds of Malmon and others (2009); Cottonwood beds of House and Faulds (2009); and Riverside beds of Faulds and others (2001) and House and others (2005). It is possible that deposits on the east shore of Lake Havasu, $\sim 1 \mathrm{~km}$ south of Blankenship Point (lat $34.5813^{\circ}$ N., long $114.4185^{\circ}$ W.), correlate to Bouse Formation (unit Tboss), but this is presently indeterminate. Thickness less than $4 \mathrm{~m}$

Qcp Alluvium of Palo Verde Mesa (lower(?) Pleistocene) - Local mantles of darkly varnished and well-rounded gravel and sand deposited by the ancestral Colorado River. Present only at the extreme southern edge of the California part of this quadrangle as lag drapes on irregular, hummocky remnants of fine-grained siliciclastic deposits of the Bouse Formation (Tboss). Unit is intact and more extensive in the adjacent quadrangle (Havasu Lake 7.5'). Includes rich assortment of pebbles and cobbles originally derived from distant sources. Quartzite cobbles very common. Gravel clasts have moderate to dark varnish. Slight to moderate reddening of varnished clasts is common. Unit bears strong similarities to Bullhead Alluvium gravels in gross appearance, but are associated 
with an array of younger fluvial terrace remnants immediately south of the map area in the Havasu Lake quadrangle. Treads of those terraces stand approximately $107-110 \mathrm{~m}$ above Lake Havasu, contain moderately rare clasts of re-worked and rounded petrified wood fragments, and are overlain by old piedmont alluvial deposits that postdate the Bullhead Alluvium (House, 2016). In the Havasu Lake quadrangle, immediately to the south, terraces of Qcp truncate thin tributary fan deposits containing reworked pea gravel and small cobbles of the Colorado River. These tributary deposits truncate the Bouse Formation (Tboss). Thickness in this map area less than $1 \mathrm{~m}$

QTcb Boulder conglomerate (lower(?) Pleistocene to Pliocene)-Boulder and coarse-cobble-enriched deposits of the ancestral Colorado River. Poorly to moderately sorted deposits of locally derived, predominantly granitic boulders in a matrix of Colorado River gravel and sand from distant sources. Unit appears to contain no far-travelled clasts larger than medium cobbles, but includes boulders up to $1.75 \mathrm{~m}$ in diameter from local sources. Some exposures in the Blankenship Bend area include discontinuous trains of large, imbricated and subrounded boulders. Imbrication indicates south, southeast, and east directed transport paths that conform to local topographic constraints. Boulder fraction of this unit chiefly derived from erosion of underlying boulder fanglomerate units Tfo and Tgf. Maximum exposed thickness is about $30 \mathrm{~m}$ near Blankenship Bend. Conglomerate is mostly flat lying with an irregular and locally deep erosional contact in underlying strata. Locally it grades upwards into finer gravel. On the California side of the river a similar boulder conglomerate is exposed as patchy remnants atop unit Tfo upslope from the prominent scarp mentioned in the description of unit Qchg. These boulders are moderately weathered and occupy a landscape position at least $20 \mathrm{~m}$ above the highest boulders at Blankenship Bend. Clast imbricated at this level indicate a south-southeast transport direction. Boulder conglomerate may be correlative to the Conglomerate of Laughlin (Faulds and others, 2001) and the Boulder conglomerate of Bat Cave Wash (Howard and others, 2015), but these possible correlations are unresolved at this time. Relations observed in this quadrangle are consistent with the unit including strata that record individual flood events in the lower part of the Bullhead Alluvium

Tcb Bullhead Alluvium (lower Pliocene) - Ancestral Colorado River deposit composed of weakly to moderately cemented Colorado River gravel and sand, containing abundant rounded quartzite pebbles and cobbles mixed with locally derived sediments. Unit has a distinctive cherty pea-gravel-rich facies, a distinctive quartzite-cobble-rich facies, and a polylithic sand and gravel facies. The latter is the most common. It is typically light gray to light brown with local zones of orangish-yellow oxidation, which may contain petrified wood. The gravel fraction contains diverse assemblage of pebbles and cobbles from locations well out of the map area and large cobbles to medium boulders derived from local alluvial-fan deposits. Sand fraction typically medium to coarse sand (sugary texture common) with mixture of well-rounded quartz-rich sand with clear to pink translucent quartz grains mixed with well-rounded to subangular far-traveled and locally derived arkosic sands. Deposits are moderately to well-sorted. Strong imbrication fabric is common in gravelly intervals, while elaborate cross-bedding is common in sandy intervals. Some outcrops show excellent sorting and clast structure; others, particularly boulder-rich intervals, are moderately sorted and have sandy matrix. Outcrops of the unit are located near the southern edge of the map where at least $5 \mathrm{~m}$ of tabular bedded cross-stratified pebble-cobble gravels are exposed. A local exposure showing a tilted (dipping $10^{\circ} \mathrm{SW}$ ), possibly faulted part of the unit, was found at lat $34.5749^{\circ} \mathrm{N}$, long $114.4285^{\circ} \mathrm{W}$. Pristine and presumably in situ petrified wood fragments have been identified in three locations in the quadrangle. One near Jops Harbor, Ariz., where the wood is present in a sandy gravel facies containing large rip-ups of Bouse Formation marl (Tbocm); the other two in the Blankenship Bend area in stratigraphic association with the boulder conglomerate unit QTcb. At Jops Harbor, the unit overlies Tbocm and includes large rip-up clasts of that unit within a sandy and pea-gravel-rich variant. This unit unconformably overlies Tfo and slightly tilted Tgf at Blankenship Bend, where it fills a paleochannel near the apex of the bend. It overlies the Bouse Formation (Tbocm and Tbogs) at Clear Bay, California; and it overlies Tac along parts of the top of the Castle Rock bluffs between the southeast edge of the map and Castle Rock Bay. The latter deposits contain rare rip-up blocks of Tbocm and some small, locally derived, boulders. South of Clear Bay, it overlies flat-lying Bouse Formation marl 

mud, and bedded limestone and marl. Underlain at many sites by distinctly oxidized zone in older units and, commonly, thin beds of oxidized sand and gravel reworked from those units, likely by wave action (Tbogs and Tbogg). Here, the Bouse is divided into two facies: a basal carbonate (Tbocm) composed of limestone and marl and a siliciclastic facies (Tboss) with interlayered beds of claystone and quartz-rich sand. In the highest outcrops in this quadrangle, unit Tbocm overlies relatively thin beds of indurated, calcareous, and cross-bedded sands. In these outcrops, the basal sands and the carbonate sediments exhibit intricate drapes that conform to irregular topography in underlying strata

Tbos

Tbocm

Tbogs

Tbogg

\section{BASIN-FILL SEDIMENTS (POST-EXTENSIONAL)}

TfC

Clay, silt, and sand-Moderately to very well sorted and interbedded fine sand, silt, and clay, possibly deposited in a delta of the nascent Colorado River. Includes sequences of quasirhythmic, laminated mudstones interbedded with planar-laminated to thinly bedded, fine- to medium-grained, rounded, quartz-rich sand. Muds are gypsiferous in places and alternate in color from light greenish gray to grayish orange pink. Sand beds are pink to pinkish gray and have thin oxidized laminae that are reddish yellow. Sand has abundant rounded quartz grains that range from translucent to pinkish. Sands are almost certainly derived from the Colorado River. Unit commonly contains some amount of subangular to subrounded locally derived sands as well. Paleontological analysis of two samples from this unit (see map and table 1) proved barren of microfossils. Maximum exposed thickness is about $15 \mathrm{~m}$

Marl or limestone - White to gray, thinly bedded to massive limestone, marl, and rare travertine. Occurs as onlapping beds on bedrock and fanglomerate. Locally shows obvious draping over irregular topography formed on bedrock and older basin deposits. In this quadrangle, the lowest Bouse Formation carbonate outcrop $(146 \mathrm{~m})$ is at the level of the lake but can be seen to extend a few meters below the lake surface and the highest outcrop ( $299 \mathrm{~m})$ is on the upper piedmont of the Chemehuevi Mountains. These outcrops lie $6.7 \mathrm{~km}$ apart on a nearly east-west line just below the middle of the map. In some of the highest exposures on the Chemehuevi piedmont, a thick bed of well-sorted oxidized sand (Tbogs) is found between $1.5 \mathrm{~m}$ of marl and several meters of siliciclastic sediments (Tbos). At the lowest exposure on the shore of Lake Havasu at Clear Bay, flat-lying and cross-bedded, weakly to moderately oxidized yellowish sand underlies $2 \mathrm{~m}$ of well-bedded limestone. The sands contain rounded quartz grains mixed with subangular lithic-rich locally derived sands (Tbogs). Here, the Bouse may interfinger with fan gravel containing 10-20 $\mathrm{cm}$ rounded mud balls. Marl bed(s) with desiccation cracks and gastropod fossils are present at this location (K.A. Howard, U.S. Geological Survey, written commun., 2017)

Golden sand facies-Moderately well sorted subangular to subrounded and strongly to moderately oxidized orange-yellow fine to coarse sand below the basal carbonate of the Bouse Formation. Cross-stratification common in good exposures. Rarely observed as interbeds within the marl. Commonly associated with Tbogg. Oxidation is common and locally pervasive, extending as a zone into underlying strata or as a stain on underlying bedrock. Most commonly associated with clastic substrates (fanglomerate or colluvium) from which particles were winnowed, milled, and sorted, likely by wave or current action (for example, Buising, 1990)

Golden gravel facies - Moderately well sorted, subangular to subrounded, and strongly to moderately oxidized orange-yellow pebble to cobble gravel below the basal carbonate of the Bouse Formation. Cross-stratification common in good exposures. Rarely observed as interbeds within the marl. Commonly associated with Tbogs. Oxidation is common and locally pervasive, extending as a zone into underlying strata or as a distinct stain on underlying bedrock. Most commonly associated with clastic substrates (fanglomerate or colluvium) from which particles were winnowed, milled, and sorted by wave or current action

Paleochannel-fill conglomerate (lower Pliocene to upper Miocene) - Boulder and cobble-rich alluvial fill in pre-Colorado River, north- to south-directed paleochannels. This includes an approximately $8-\mathrm{m}$-thick boulder conglomerate filling a distinct paleochannel that is 
cut into steeply dipping fanglomerate (Tgf) that forms steep bluffs along the south side of Trampas Wash at lat $34.600 \mathrm{~N}$, long $114.454 \mathrm{~W}$. The paleochannel contains locally derived, subrounded granitic boulders up to $1.25 \mathrm{~m}$ in diameter. Most, if not all, boulders are lithologies from the Chemehuevi Mountains Plutonic Suite. No far-travelled lithologies typical of Colorado River gravels observed in this unit. Approximate orientation of channel suggests south-southeast transport direction $\left(140^{\circ}\right)$. Unit also contains a set of several similar but smaller channels that also cut steeply dipping fanglomerate on the south side of the valley of Trampas Wash nearer its mouth. These channels lie lower in the landscape and are probably inset below the larger boulder-filled channel to the west. They contain matrix-supported, subangular, locally derived cobbles and are oriented in a south-southeast direction

Tac Alluvium of Castle Rock (upper Miocene) - Poorly sorted, moderately bedded sand, gravel, and silt of local origin, rare angular to subrounded boulders. Gravel clasts reflect locally derived lithologies. Deposits are moderately to strongly indurated and gently south dipping. Includes some thin intervals of dark staining and manganese cementation. Forms steep cliffs and benches along a narrow band flanking the eastern shore of Lake Havasu. Castle Rock is an isolated remnant of this unit. Unit is probably an axial valley equivalent to the alluvial fan deposits of unit Tfo, but the boundary between them has not been confidently identified. The upper surface of the unit in the bluffs is a possible strath terrace, which corresponds closely to the contact between Qchm and Qchs in Castle Rock Bay. It forms a flat surface ranging from 25 to $30 \mathrm{~m}$ above Lake Havasu. It is covered with patchy remnants of the Riverside terrace alluvium (Qcr3) that locally overlies small deposits of Qch and Tcb that occupy erosional niches in the unit. Unit mostly postdates mid-Miocene extensional tectonic activity and predates the arrival of the Colorado River in Chemehuevi Valley. Some of what is mapped as Tac is probably equivalent to the upper part of Tfo, and it correlates to fanglomerate of Metzger and Loeltz (1973); the fanglomerate of Osborne Wash of Dickey and others (1980); and (or) the fanglomerate of Howard and others (1999). Exposed thickness as much as $30 \mathrm{~m}$; total thickness of unit unknown

Tfo Older fanglomerate (upper Miocene) — Poorly sorted, poorly bedded, subangular to subrounded sand and gravel dominated by granitic clasts from the Chemehuevi Mountains. Includes scattered large boulders and bouldery lenses. Highly dissected surfaces with exposures up to $40 \mathrm{~m}$ thick are present south of Trampas Wash. Largely unburied remnants of this unit have a corrugated or ridge-and-ravine topographic form. Eroded surfaces lack clear soil structure and exhibit spotty retrograde pavement and varnish development on some ridge crests and in hollows on slopes. Overlain by Tcb at Blankenship Bend along a deep erosional unconformity, and overlain by the Bouse Formation in parts of the upper Chemehuevi Mountains piedmont. The former relation indicates the unit once extended across the modern valley axis; the latter relation indicates that the relict deposits were once part of a large alluvial fan complex at the foot of the Chemehuevi Mountains. It is likely that this unit was graded into unit Tac prior to the integration of the Colorado River. Colorado River sediments (Qch) are inset into valley-facing scarps $2-5 \mathrm{~m}$ high, cut into this unit near the $620-\mathrm{ft}(189-\mathrm{m})$ contour on the California side of Lake Havasu. Isolated and irregular lags of rounded Colorado River gravels are scattered on slopes above (to west of) the scarps. Unit corresponds to unit To (Fanglomerate of Osborne Wash) of Dickey and others (1980) and may contain some amount of unit Tgf as described by John (1988) and shown on this map. May be stratigraphically equivalent to parts of unit Q1 of Bull (1991); units Q1b and (or) QT1a of Dickey and others (1980); unit QTa of Miller and John (1999); unit QTs1 of Howard and others (1999); unit Tf of Spencer and others (2015); and unit Tfg1 of Gootee and others (2016). Thickness at least $30 \mathrm{~m}$

\section{ALLUVIAL AND MEGABRECCIA DEPOSITS (SYN-EXTENSIONAL)}

Tgf Granite-clast fanglomerate (Miocene) - Light-tan- and orange-weathering, virtually monomictic alluvial-fan deposits, composed of white to tan granite and granodiorite clasts; clasts of dike rock types, equivalent of rocks below the Chemehuevi detachment fault; and clasts of altered cataclasite. Locally contains thin siliceous tuff beds and basalt flows. Miller and John (1999) report a ${ }^{40} \mathrm{Ar} /{ }^{39} \mathrm{Ar}$ date of $13.9 \pm 0.1 \mathrm{Ma}$ for biotite in a tuff found in this unit

Tgm Granite megabreccia (Miocene) - Light-tan- and pale-orange-weathering, granite-clast landslidemegabreccia deposits; silicified. Granite blocks up to $\sim 1 \mathrm{~km} \times 20 \mathrm{~m}$ within the deposits. 
Megabreccia deposit is composed of granitic debris characteristic of rocks below the Chemehuevi detachment fault. Locally, includes altered granitic cataclasite debris, possibly derived from exhumed fault scarps

Tgnf Gneiss-clast fanglomerate (Miocene) - Dark-red- to red-brown-weathering, poorly sorted alluvial-fan deposits. Includes subangular to subrounded clasts of Proterozoic gneisses (Xgn), granite (Yg), and amphibolite, characteristic of rocks above the Chemehuevi detachment fault. Miller and John (1999) report a ${ }^{40} \mathrm{Ar}{ }^{\beta 9} \mathrm{Ar}$ age of $15.24 \pm 0.02 \mathrm{Ma}$ from biotite in a tuff in this unit

Tgnm Gneiss-clast megabreccia (Miocene) - Dark-reddish-brown-weathering, gneissic- and graniteclast, landslide-megabreccia deposits containing silicified landslide blocks up to $500 \times 20$ $\mathrm{m}$. Megabreccia deposits composed of debris of gneissic and granitic rocks characteristic of rocks above the Chemehuevi detachment fault

Tvf Volcanic-clast fanglomerate (Miocene) —Dark-reddish-brown, poorly sorted alluvial fan deposits, composed of mainly intermediate and mafic-volcanic clasts in a sandy matrix. The fanglomerate is in gradational contact with unit Tgnf and contains clasts characteristic of rocks above the Chemehuevi detachment fault, including Peach Spring Tuff (Tps). Boulders up to $1 \mathrm{~m}$ in diameter are present

Tvm Volcanic-clast megabreccia (Miocene) - Dark-reddish-brown-weathering, volcanic-clast, landslide-megabreccia deposits containing silicified landslide blocks up to $500 \times 20 \mathrm{~m}$. Megabreccia deposit is composed of volcanic debris characteristic of rocks above the Chemehuevi detachment fault

Tvpm Peach Spring Tuff megaclast (Miocene) - Single megaclast of Peach Spring Tuff measuring approximately $275 \times 30 \mathrm{~m}$

Sedimentary breccia (Miocene) - Angular to subrounded cobbles and pebbles in a poorly sorted, mudrich matrix; the rock is always matrix rich but may be matrix or clast supported. Crude parallel stratification on a $30-\mathrm{cm}$ to $1-\mathrm{m}$ scale is visible in some places (fig. $11 B$ ) but is usually poorly developed. Individual beds are generally massive; inverse to normal grading is rare. The higher proportion of matrix and less-well-developed stratification distinguish sedimentary breccia from conglomerate

\section{CENOZOIC VOLCANIC ROCKS AND SEDIMENTS}

Basalt (Miocene) - Dark-purplish-brown, augite-olivine basalt flows, dikes, and plugs. Flows have conspicuous columnar joints. Locally intrudes and fuses cataclastites associated with the Chemehuevi detachment fault. K-Ar whole-rock age of $11.1 \pm 0.4$ and $14.5 \pm 1.0$ Ma by M.A. Pernokas (written commun. in John, 1987); however, this sample is not from basalt exposed in the map area

Tss Sandstone (Miocene) - Pale-brown to very pale brown sandstone and siltstone. Sandstone is well bedded and moderately to well sorted. Composed of thin to medium beds of fine to medium sand with thin lenses to discontinuous medium beds of pebble gravel conglomerate and medium beds of siltstone. Planar bedding and cross-bedding are common, and rare oscillatory ripples and mud cracks are present. In at least one location, unit is overlain along an angular unconformity by incised gravelly paleochannels within unit Tvf

Tps Peach Spring Tuff (Miocene) - Non-welded to densely welded, white to pink, ash-flow and air-fall tuff. Commonly devitrified showing vapor-phase alteration. Phenocrysts 5 to 10 percent, predominately blue sanidine, plagioclase, and quartz, with rare biotite, hornblende, pyroxene, and sphene. Recent dating of this unit indicates an age of $18.78 \pm 0.02$ and identifies a source vent near Bullhead City, Arizona (Ferguson and others, 2013)

Ts Sandstone and conglomerate (Miocene) - Epiclastic conglomerate and sandstone. Range in thickness from several meters where exposed in this quadrangle to several hundred meters in other areas. Includes interbedded volcanic rocks that commonly include andesitic lahar deposits low in the section, basalt and plagioclase-phyric ("jackstraw") andesitic or latitic flows and plugs at intermediate levels, and fine-grained mafic flows high in the section. Sedimentary interbeds include arkose near the base of the volcanic section and volcanic-clast tuffaceous conglomerate high in the section

Volcanic flows and intrusions (Miocene and Oligocene(?)) - Mafic, intermediate and silicic volcanic flows and small hypabyssal intrusions. Locally includes intensely altered and fractured biotite dacite porphyry intrusions along and below the Chemehuevi detachment fault in the southern Chemehuevi Mountains. Some dacite flows and intrusions are syntectonic with detachment faulting 


\section{MESOZOIC PLUTONIC ROCKS}

Chemehuevi Mountains Plutonic Suite of John and Wooden (1990)

Kg Two-mica granodiorite and monzogranite (Cretaceous)-Medium- to coarse-grained, leucocratic subequigranular to porphyritic two-mica granodiorite and monzogranite. The rocks weather light tan and contain microcline phenocrysts up to $1.5 \mathrm{~cm}$ across in a coarse-grained (5-8 mm) groundmass of quartz, plagioclase, orthoclase (2-4\%), biotite (1-2\%), muscovite (1-2\%), and accessory magnetite, apatite, allanite, epidote, zircon, and rare sphene and monazite. Locally, surrounds irregular blocks of porphyritic biotite granodiorite and monzogranite (Kpg), suggesting that unit Kpg is older. Elsewhere the contact relations are ambiguous

Kpg Chemehuevi Peak Granodiorite (Cretaceous) - Porphyritic biotite granodiorite and monzogranite. Forms the most voluminous unit of the Chemehuevi Mountains Plutonic Suite: light-tan to gray, medium- to coarse-grained, subporphyritic to porphyritic, biotitesphene granodiorite and monzogranite. Zoned microcline megacrysts, measuring up to 6 $\mathrm{cm}$ across, make up as much as $40 \%$ of the volume of the rock; they are set in a mediumgrained groundmass consisting of quartz, plagioclase, microcline, and biotite (5-12\%), with coarse accessory sphene and allanite-cored epidote euhedra (up to $2 \mathrm{~mm}$ ), magnetite, apatite, zircon, and rare primary muscovite

Kbg Biotite granodiorite (Cretaceous) - Light-gray to tan, subequigranular biotite granodiorite. Biotite is the most abundant mafic phase (up to $12 \%$ ) and is typically euhedral (up to $5 \mathrm{~mm}$ ), associated with rare blue-green hornblende. Perthitic microcline and quartz are interstitial. Sphene (up to $2 \%$ ) occurs as euhedral crystals (up to $2 \mathrm{~mm}$ ) and as overgrowths on magnetite. Apatite and zircon occur in and near the magnetite. Metamict subhedral allanite grains up to $1-2 \mathrm{~mm}$ are rare throughout this phase and commonly have euhedral epidote overgrowths. Borders of this unit against the porphyritic hornblende-biotite granodiorite and Proterozoic gneisses are fine to medium grained and contain rare potassium feldspar megacrysts up to $4 \mathrm{~cm}$ long. Inward, away from the older rocks, these phenocrysts increase in abundance and primary igneous flow structures appear. Mineralogically, the biotite granodiorite is nearly identical to the porphyritic granodiorite, but has rare hornblende

Kgd Porphyritic hornblende-biotite granodiorite (Cretaceous) - Border unit of the Chemehuevi Mountains Plutonic Suite. Gray, medium-grained, quartz-poor, variably porphyritic, hornblende-biotite granodiorite. The granodiorite includes small equant microcline phenocrysts (up to $1 \mathrm{~cm}$ ), stubby blue-green hornblende (4-20\%), euhedral biotite $(2-5 \%)$, coarse sphene (1-3\%), and accessory magnetite, allanite, epidote, and zircon. The epidote is considered late magmatic based on textural relations. The granodiorite is deformed and bears a mylonitic foliation and subhorizontal lineation

\section{Whale Mountain sequence}

KJqd Hornblende-biotite quartz diorite and quartz monzodiorite (Cretaceous or Jurassic) - Darkgray to brown concordant bodies (up to $1 \times 4 \mathrm{~km}$ in plan view) of hornblende-biotite quartz diorite and quartz monzodiorite. This phase is characterized by plagioclase phenocrysts up to 3-4 mm, in a matrix of $18-38 \%$ medium-grained, blue-green hornblende and blue-green biotite, with accessory sphene, magnetite, apatite, and zoned allanite with overgrowths of epidote. Along the north flank of the Chemehuevi Mountains, these rocks bear a steeply dipping mylonitic foliation and subhorizontal lineation. Rocks south of Chemehuevi Peak, in the lowlands along the south flank of the range, are undeformed and intrude nonmylonitic Proterozoic gneisses and amphibolites (Xgn)

qm Biotite monzogranite to syenogranite (Cenozoic or Mesozoic) - Tan, coarse-grained, weakly foliated, subequigranular monzogranite to syenogranite. Contains sparse euhedral biotite (up to $2 \%$ )

\section{PROTEROZOIC ROCKS}

Yg Porphyritic monzogranite (Mesoproterozoic) — Tan to pale-red, coarse-grained porphyritic biotite granodiorite to monzogranite. Dark-gray, tabular potassium-feldspar megacrysts (up to $4 \mathrm{~cm}$ ), typically rimmed by plagioclase, sit in a matrix of plagioclase, quartz, potassium feldspar, biotite, rare hornblende, magnetite, and sphene. These rocks are considered equivalent to the 1.4- to 1.5-Ga anorogenic granites discussed by Anderson 
(1983), based on textural, compositional, and mineralogical similarities to granites at Parker Dam and Davis Dam

Xgn Gneiss and migmatite (Paleoproterozoic) - Heterogeneous crystalline rocks including migmatite granite and amphibolite-facies orthogneiss and paragneiss. Layered gneiss, the most common rock, consists of leucocratic, biotite \pm garnet-bearing quartzo-feldspathic gneiss and is associated with subordinate coarse pegmatite, biotite schist, amphibolite to hornblendite, and rare augen gneiss. Lowlands along the south flank of the Chemehuevi Mountains expose a complex of garnet-bearing leucocratic granitic gneiss, amphibolite, pegmatite, and fine-grained, laminated, biotite quartzo-feldspathic gneiss. The age of the unit is uncertain; south of Red Rock Wash, near Devils Elbow in the Topock quadrangle, the gneisses are intruded by undeformed coarse-grained porphyritic monzogranite (Yg). This relation suggests that the unit of gneissic rocks is older than $1.4 \mathrm{Ga}$ and, based on regional knowledge, is probably $\sim 1.7 \mathrm{Ga}$ (Howard and others, 2013)

Xmgn Mylonitized gneiss and migmatite (Paleoproterozoic)-Mylonitized, heterogeneous crystalline rocks including migmatite, granite, and amphibolite-facies orthogneiss and paragneiss. Probably mylonitic equivalent to Xgn. In the central and eastern Chemehuevi Mountains, layered gneiss has a superposed shallow-dipping, northwest-striking mylonitic foliation and, locally, a subhorizontal mylonitic lineation. Equivalent rocks in the northwestern part of the range near Whale Mountain have a steep, northeast-striking foliation and a subhorizontal mylonitic lineation

Table 1. Data for microfossil samples collected by P.K. House and analyzed by Kristin McDougall.

[USGS No., micropaleontology laboratory numbering system. Field No., sample identification designated by field geologist. Quadrangle, 7.5' quadrangle and state where sample collected. Locality, description related to geographic or stratigraphic location of sample. Latitude and Longitude, latitude and longitude of sample location entered as decimal degrees. All locations are NAD83. Accuracy of location is approximate. Lithologic unit, formal stratigraphic unit name at time of work. Fossils, fossil groups observed in residues. Comments, any commentary related to sample including, but not limited to, lithology, elevation, age, and ecology. Table modified from McDougall and Martinez (2014)]

\begin{tabular}{|c|c|c|c|c|c|c|c|c|}
\hline $\begin{array}{c}\text { USGS } \\
\text { No. }\end{array}$ & Field No. & Quadrangle & Locality & Longitude & Latitude & $\begin{array}{c}\text { Lithologic } \\
\text { unit }\end{array}$ & Fossils & Comments \\
\hline Mf12892 & 2071304-05 & $\begin{array}{l}\text { Castle Rock, } \\
\text { AZ }\end{array}$ & $\begin{array}{l}\text { Sample from base of } \\
\text { slope in greenish- } \\
\text { yellow, fissile clay } \\
\text { (mud). Overlain, } \\
\text { eroded, and loaded } \\
\text { by } 3-5 \text { m thick sand } \\
\text { body which makes up } \\
\text { most of slope. Mud } \\
\text { interval } 2 \mathrm{~m} \text {. Sand } \\
3-5 \text { m, overlain by } \\
\text { considerably more and } \\
\text { younger sediment }\end{array}$ & -114.431 & 34.504 & $\begin{array}{c}\text { Bouse } \\
\text { Formation }\end{array}$ & $\begin{array}{l}\text { Barren of } \\
\text { foraminifers } \\
\text { and other } \\
\text { organics }\end{array}$ & $\begin{array}{l}\text { Sample elevation } \\
640 \text { feet } \\
(195.72 \mathrm{~m})\end{array}$ \\
\hline Mf12895 & 2071302 & $\begin{array}{l}\text { Castle Rock, } \\
\text { AZ }\end{array}$ & $\begin{array}{l}\text { Metzger's interbedded } \\
\text { unit. Interbedded } \\
\text { 'suicide mud' and fine } \\
\text { (likely) CR sand }\end{array}$ & -114.424 & 34.507 & $\begin{array}{c}\text { Bouse } \\
\text { Formation }\end{array}$ & $\begin{array}{l}\text { Barren of } \\
\text { foraminifers } \\
\text { and other } \\
\text { organics }\end{array}$ & $\begin{array}{l}\text { Sample elevation } \\
182.88 \mathrm{~m}\end{array}$ \\
\hline
\end{tabular}




\section{References Cited}

Anderson, J.L., 1983, Proterozoic anorogenic granite plutonism of North America: Geological Society of America Memoir 161, p. 133-154.

Buising, A.V., 1990, The Bouse Formation and bracketing units, southeastern California and western ArizonaImplications for the evolution of the proto-Gulf of California and the lower Colorado River: Journal of Geophysical Research, Solid Earth, v. 95, no. B12, p. 20111-20132. Bull, W.B., 1991, Geomorphic responses to climatic change: New York, Oxford University Press, $326 \mathrm{p}$.

Dickey, D.D., Carr, W.J., and Bull, W.B., 1980, Geologic map of the Parker NW, Parker, and parts of the Whipple Mountains SW and Whipple Wash quadrangles, California and Arizona: U.S. Geological Survey Miscellaneous Investigations Series Map I-1124, scale 1:24,000.

Faulds, J.E., House, P.K., Ramelli, A.R., Bell, J.W., and Pearthree, P.A., 2001, Preliminary geologic map of the Davis Dam quadrangle, Clark County, Nevada, and Mohave County, Arizona: Nevada Bureau of Mines and Geology Open-File Report 03-5, scale 1:24,000, https://ngmdb.usgs. gov/Prodesc/proddesc_59586.htm.

Ferguson, C.A., McIntosh, W.C., and Miller, C.F., 2013, Silver Creek caldera-The tectonically dismembered source of the Peach Spring Tuff: Geology, v. 41, no. 1, p. 3-6.

Gootee, B.F., Pearthree, P.A., House, P.K., Youberg, A., Spencer, J.E., and O'Connell, B., 2016, Geologic map of the Cibola area, La Paz County, Arizona, and Imperial County, California: Arizona Geological Survey Digital Geologic Map DGM-112, scale 1:24,000. https://ngmdb.usgs.gov/ Prodesc/proddesc_105181.htm.

House, P.K., 2016, The LOCO strata; new observations, mapping, discoveries, and ideas about key geologic deposits chronicling the inception and evolution of the lower Colorado River from the Pliocene to the present, in Reynolds, R.E., ed., Going LOCO, investigations along the Lower Colorado River: Zzyzx, California, California State University Desert Studies Center, The 2016 Desert Symposium Field Guide and Proceedings, p. 65-72.

House, P.K., and Faulds, J.E., 2009, Preliminary geologic map of the Spirit Mountain NW quadrangle, Clark County, Nevada, and Mohave County, Arizona: Nevada Bureau of Mines and Geology Open-File Report 09-06, 1:24,000 scale, https://ngmdb.usgs.gov/Prodesc/proddesc_96254.htm.

House, P.K., and Pearthree, P.A., and Brock, A.L., 2005, Geologic map of late Cenozoic alluvial deposits in the Spirit Mountain SE quadrangle: Nevada Bureau of Mines and Geology Open-File Report 05-8, scale 1:24,000. https:// ngmdb.usgs.gov/Prodesc/proddesc_82899.htm.

House, P.K., Pearthree, P.A., Howard, K.A., Bell, J.W., Perkins, M.E., Faulds, J.E., and Brock, A.L., 2005, Birth of the lower Colorado River-Stratigraphic and geomorphic evidence for its inception near the conjunction of Nevada, Arizona, and California, in Pederson, J., and Dehler, C.M., eds., Interior Western United States: Geological Society of America Field Guide 6, p. 357-387, doi: 10.1130/2005. fld006(17).
Howard, K.A., Goodge, J., and John, B.E., 1982, Detached crystalline rocks of the Mohave, Buck and Bill Williams Mountains, western Arizona, in Frost, E.G., and Martin, D.L., eds., Mesozoic-Cenozoic tectonic evolution of the Colorado River region, California, Arizona, and Nevada: San Diego, California, Cordilleran Publishers, p. 377-392.

Howard, K.A., House, P.K., Dorsey, R.J., and Pearthree, P.A., 2015, River-evolution and tectonic implications of a major Pliocene aggradation on the lower Colorado River; The Bullhead Alluvium: Geosphere, v. 11, no. 1, p.1-30.

Howard, K.A., John, B.E., Davis, G.A., Anderson, J.L, and Gans, P.B., 1994, A guide to Miocene extension and magmatism in the lower Colorado River region, Nevada, Arizona, and California: U.S. Geological Survey Open-File Report 92-246.

Howard, K.A., John, B.E., Nielson, J.E., Miller, J.M.G., and Wooden, J.L., 2013, Geologic map of the Topock 7.5' quadrangle, Arizona and California: U.S. Geological Survey, Scientific Investigations Map SIM-3236, scale 1:24,000. https://ngmdb.usgs.gov/Prodesc/ proddesc $98124 . \mathrm{htm}$.

Howard, K.A., Nielson, J.E., Wilshire, H.G., Nakata, J.K., Goodge, J.W., Reneau, S.L., John, B.E., and Hansen, V.L., 1999: Geologic map of the Mohave Mountains area, Mohave County, western Arizona: U.S. Geological Survey Miscellaneous Investigations Series Map I-2308, scale 1:48,000, https://ngmdb.usgs.gov/ Prodesc/proddesc_26881.htm.

John, B.E., 1987a, Geologic map of the Chemehuevi Mountains area, San Bernardino County, California, and Mohave County, Arizona: U.S. Geological Survey Open-File Report 87-666.

John, B.E., 1987b, Geometry and evolution of a mid-crustal extensional fault system, Chemehuevi Mountains, southeastern California: London, Geological Society, Special Publications, no. 28, p. 313-335.

John, B.E., 1988, Structural reconstruction and zonation of a tilted mid-crustal magma chamber; the felsic Chemehuevi Mountains Plutonic Suite: Geology, v. 16, no. 7, p. 613-617. https://ngmdb. usgs.gov/Prodesc/proddesc_63327.htm.

John, B.E., and Wooden, J., 1990, Petrology and geochemistry of the metaluminous to peraluminous Chemehuevi Mountains Plutonic Suite, southeastern California: Geological Society of America Memoirs, v. 174, p. 71-98.

LaForge, J.S., John, B.E., and Grimes, C.B., 2017, Synextensional dike emplacement across the footwall of a continental core complex, Chemehuevi Mountains, southeastern California: Geosphere, v. 13, no. 6, p. 1867-1886, DOI: https://doi. org/10.1130/GES01402.1.

Machette, M.N., 1985, Calcic soils of the southwestern United States: Geological Society of America Special Papers, no. 203, p. 1-22.

Malmon, D.V., Howard, K.A., and Priest, S.S., 2009, Geologic map of the Needles 7.5' quadrangle, California and Arizona: U.S. Geological Survey Scientific Investigations Map 3062, scale 1;24,000, 1 sheet, pamphlet 31 p., https://pubs.usgs.gov/sim/3062/.

Malmon, D.V., Howard, K.A., House, P.K., Lundstrom, S.C., Pearthree, P.A., Sarna-Wojcicki, A.M., Wan, Elmira, and Wahl, D.B., 2012, Stratigraphy and depositional environments of the Upper Pleistocene Chemehuevi Formation along the lower Colorado River [type area, Katherine Landing, Lake Mead, Arizona]: U.S. Geological Survey, Professional Paper 1786, scale 1:17,200. https://ngmdb.usgs.gov/Prodesc/proddesc_96497.htm. 
McDougall, K., and Martinez, A.Y.M., 2014, Evidence for a marine incursion along the Colorado River corridor: Geosphere, v. 10 , no. 5 , p. $842-869$.

Metzger, D.G., and Loeltz, O.J., 1973, Geohydrology of the Needles area, Arizona, California, and Nevada: U.S. Geological Survey Professional Paper 486-J, 46 p.

Metzger, D.G., Loeltz, O.J., and Irelan, B., 1973, Geohydrology of the Parker-Blythe-Cibola area, Arizona and California: U.S. Geological Survey Professional Paper 486-G, 129 p.

Miller, J.M.G., and John, B.E., 1999, Sedimentation patterns support seismogenic low-angle normal faulting, southeastern California and western Arizona: Geological Society of America Bulletin, v. 111, no. 9, scale 1:37,000.
Spencer, J.E, Pearthree, P.A., House, P.K., and Reynolds, S.J., 2015, Geologic map of the Cross Roads 7.5' quadrangle and the southern part of the Gene Wash 7.5' quadrangle, La Paz County, Arizona, and San Bernardino County, California: Arizona Geological Survey, Digital Geologic Map DGM-111, scale 1:24,000. https://ngmdb.usgs.gov/Prodesc/ proddesc_105181.htm.

Wilshire, H.G., and Reneau, S.L., 1992, Geomorphic surfaces and underlying deposits of the Mohave Mountains piedmont, lower Colorado River, Arizona: Zeitschrift fur Geomorphologie, v. 2, no. 36 , p. 207. 